\title{
Citrus Canker in Sudan: Etiology and Epidemiology
}

\author{
Elshafia Ali Hamid ${ }^{1}$, Siddig Mohamed Elhassan ${ }^{2}$ and Azza Siddig Hussien Abbo ${ }^{2}$ \\ ${ }^{1}$ Department of Plant Pathology, Agricultural Research Corporation, Edamar, Sudan \\ ${ }^{2}$ Department of Crop Protection, University of Khartoum, Shambat, Sudan
}

Submission: March 01, 2021; Published: March 15, 2021

"Corresponding author: Elshafia Ali Hamid, Department of Plant Pathology, Agricultural Research Corporation, Edamar, Sudan

\begin{abstract}
Citrus bacterial canker disease (CBCD) caused by Xanthomonas citri subsp. citri (Xcc), is one of the most destructive diseases to the citrus plantations worldwide, newly invaded, and threatened citriculture in Sudan. Occurrence and spread of CBCD in Sudan have been surveyed in two states, representing the main citrus producing states in Sudan. Field surveys were conducted during January 2015 in commercial citrus orchards and nurseries at the two locations. Symptomatology, host range study, physiological and biochemical characterization of the isolated pathogen were also carried out to obtain important clues on pathogen identification. In addition, the pathogenicity test was performed on detached leaves of several selected citrus varieties such as grapefruit, orange and lime to establish the identity of the presumptive Xanthomonas citri subsp. citri (Xcc). The disease on lime orchards in northern and southern Sawagi (Kassala State) recorded a disease incidence of $66.6 \%$ and $18 \%$, respectively. In nurseries, the disease incidence attained $51.7 \%$ and $53.6 \%$ in northern Sawagi and southern Sawagi, respectively, while in Khartoum State the disease was unexpectedly detected at a considerably high incidence of $45 \%$, but at only one nursery, no disease detected in Khartoum State`s orchards during these surveys. Lime trees displayed typical symptoms of CBCD, but nearby canker-susceptible citrus species, such as grapefruit (C. paradisi) and sweet orange (C. sinensis) were unaffected. Typical symptoms of CBCD were noticed on leaves, twigs, fruits and branches. The pathogenicity tests of the recovered canker isolates induced typical lesions on local lime only, but produced atypical lesions on other citrus varieties. All the biochemical and physiological characteristics obtained from the re-isolations were also indicative of the presence of Xcc. As important perspectives, it appeared that these citrus canker isolates were distinctive and specific on lime. They were very similar to the pathotype $A^{*}\left(X_{c c}-A^{*}\right)$ and they attained an epidemic level in Kassala State.
\end{abstract}

Keywords: Citrus bacterial canker; Severity scale; Pathogenicity; Pathotype

\section{Introduction}

Citrus (Rutaceae family) is considered as one of the most important commercial fruit crops. Sudan, with all its vast area, wide range of soils, diverse climatic conditions, and ample water resource possesses great potentials for citrus production. At present, the commercial citrus production in Sudan spreads all over the country, mainly along the narrow strips of alluvial soils of the main River Nile, Blue Nile, and White Nile. In addition, it is also extending to the banks of annual valleys and rivers and upper terraces in which underground water is available for irrigation [1]. The important citrus groups have grown commercially in Sudan include: Small fruited acid lime (Citrus aurantifolia Swingle), grapefruit (C. paradise Macfad), sweet orange (C. cinensis Osbeck), and Mandarins (C. reticulate Blanco). Each group is composed of several varieties and selections (Ali-Dinar, 1984).
The total area of citrus production in Sudan is estimated around 171,192 hectares with a total production of 2.3 million tons and exportation amounting to 9.8 thousand tons, for years (20102013) (National Horticulture Administration, 2013). Therefore, the national strategy of citrus expansion is directed towards the large national schemes, e.g. Gezira, Suki, Rahad and the Blue Nile Schemes in the Central Clay Plain [2]. Although the citrus crop is kept in great esteem, yet its present status is threatened by several problems, including low productivity caused by diseases. The citrus tree is attacked by several diseases in Sudan like gummosis, citrus decline, Tristeza virus, and virus-like diseases [3]. More recently a new aggressive disease was discovered in Gadaref State on lime with typical symptoms of citrus bacterial canker [4]. 
Citrus bacterial canker disease (CBCD) caused by Xanthomonas citri subsp. citri (Xcc) is probably one of the most devastative to the citrus plantations at the global level. Citrus canker is thought to have originated from South East Asia or India and spreading in more than 30 countries throughout the world, including countries in the Middle East, the Horn of Africa, and some other countries in South and West Africa [5,6]. Citrus canker disease is occurrence regularly on several citrus cultivars in varying degrees of incidence depending on the climatic conditions. The bacterium causes different symptoms ranging from pustules to necrotic lesions consisting of erumpent corky tissue surrounded by water soaked tissues and yellow halo on leaves, stems, and fruits [712]. As such, disease severity on susceptible variety results in defoliation, dieback, premature fruit drop, and blemished fruit, which consequently decrease fruit production and market value [13]. Also, the citrus canker has had a serious impact on local citrus industries whenever infections have been detected. As a result, millions of dollars are spent annually on prevention, quarantine, eradication programs, and chemical control [14]. Three main types of citrus canker bacteria have been identified, which possess variations in host range among citrus varieties.

The pathotype A (the Asiatic type of canker, Xcc) is the most destructive and widespread variant of the disease among most commercial citrus varieties and their relatives. The pathotypes B and $C$ of citrus canker are caused by Xanthomonas fuscans subsp. Aurantifolii. Cancrosis B and cancrosis C are limited in host range and are geographically restricted to South America [15]. Certain distinctive groups within pathotype $A(X c c)$ have also been identified which have restricted host range. For instance, pathotype $A^{*}$ strains with a host range restricted only to Mexican lime (Citrus aurantifolia) but not infecting citrus canker susceptible species, grapefruit and sweet orange, have been described in several countries in The Middle East and also reported from Thailand, Mali, Ethiopia, and Burkina Faso (Derso et al., 2009). Recently Elhassan et al., [4] reported the presence of CBCD for the first time on lime trees in Gadaref State (Sudan) depending on the visual symptoms, pathogenicity tests, and some biochemical characteristics of the causal bacterium isolate, which closely resemble the atypical Asiatic form of CBC $\left(X c c-A^{*}\right)$. Now the disease seems to flareup and spread to most of the citrus groves in Gadaref and Kassala states. It was also observed to spread in nurseries of Khartoum North. In general, the environmental conditions, particularly the climate are conducive to CBCD development in the remaining areas of all southeastern region of Sudan. Apparently, a high infection potential dominates the epidemiological stage in this region. The study was conducted to survey the natural occurrence, citrus varietal susceptibility, symptomatology, disease severity and extent of spread of citrus bacterial canker disease (CBCD) in commercial citrus orchards and nurseries in Kassala and Khartoum states, it was also aimed to confirm the identity of the causal pathogen depending on phenotypical characteristics and the pathogenicity of the bacterium isolates.

\section{Material and Methods}

\section{Field survey and disease pathometry}

The survey was carried out in January 2015 after the end of the rainy season in two different locations (Kassala and Khartoum states). In Kassala State, the survey was conducted in North Sawagi and South Sawagi areas, while in Khartoum State, the survey was conducted at Shambat in Khartoum North and at Almogran in Khartoum. The survey included inspection of two main citrus planting types namely, commercial orchards and nurseries. 6 orchards and nurseries per location at Kassala State and 4 from each were inspected at Khartoum State. Two hundred lime trees, in addition to 30-100 orange, mandarin, and grapefruit trees, whenever available, were examined in the same orchard inspected for the presence of CBCD. Also, all nursery stocks found at the selected sites were examined for CBCD. The main objectives of the survey were to discover the occurrence and extent of the spread of citrus bacterial canker disease (CBCD) and study its Symptomatology. Close visual observations were made and diseased plant tissues including, leaves, twigs, and fruits were collected from symptomatic plants. Disease development was then evaluated according to the following pathometry:

\section{1- Disease incidence}

The disease incidence (DI) was recorded for each planting type at these locations and the data were arranged and statistically analyzed. The calculations were based on the following formula:

DI $(\%)=$ No.of infected plants $\mathrm{x} 100 /$ total No. of plants inspected

\section{2- Disease severity}

\section{i. In orchards}

Ten trees were randomly selected at each orchard. Diagnostic symptoms were examined on leaves, fruits, twigs, branches, and the main tree stem. In severe cases, defoliation, twig dieback, and fruit drop were also considered. Disease severity (DS) was estimated at specified dates based on a 0-5 disease severity scale (SS) as the fallows:

Scale 0: non-symptomatic trees. Scale 1: leaf symptoms on few (1-3) branches, Scale 2: leaf symptoms in up to $10 \%$ of branches. Scale 3: leaf symptoms in $>10 \%-25 \%$ of the branches plus mild symptoms on fruits and twigs. Scale $4:>25 \%-50 \%$ of the tree canopy showing clear canker symptoms on leaves, fruits, twigs, in addition to defoliation and die-back. Scale 5: > 50\% of the tree canopy showing prominent canker symptoms on leaves, twigs, fruits, main branches, and trunks. Also, severe defoliation and dieback are evident. 


\section{ii. In nurseries}

Disease severity was estimated based on a 0-5 disease severity scale (SS) as follow:

Scale 0: non-symptomatic nursery plants. Scale 1: leaf symptoms on few (1-3) leaves. Scale 2: leaf symptoms on 4 to 9 leaves Scale 3: leaf symptoms on 10 to 15 of the leaves. Scale 4: leaf symptoms $>15$ leaves to $50 \%$ of the foliage. Scale 5 : > 50\% of foliage showing canker symptoms. Besides, some individual lesions on twigs and stems are evident.

The disease severity (DS) was then calculated as follow:

$$
D S=\Sigma(S S) / \text { No. of plants inspected }
$$

3- Percent disease index (DX): It was calculated according to the fallowing formula:

\section{DX $(\%)=$ DS $\times 100 / \max$ SS}

The recorded data on disease pathometry (disease incidence and disease index) were transformed using arcsine transformation, before being subjected to analysis of variance (ANOVA), as described by Gomez and Gomez (1984) for the factorial experiment in a completely randomized design. EXCEL computer package version 2010 was applied. Then the treatments means were compared using the least significant difference (LSD).

\section{Symptomatology}

Symptoms development of citrus bacterial canker infection was closely examined during the survey of the disease in each of chosen orchards and nurseries. Different parts of symptomatic trees were examined for canker lesions namely, leaves, twigs, fruits, branches, and stems. Also, leaf defoliation and die-back in twigs and branches were also observed, recorded, and photographed. The symptoms were closely noticed and described.

Isolation and purification of Xanthomonas axonopodis pv. citri

Isolation and purification of the bacteria from infected leaves, fruits, and twigs were conducted following the National Diagnostic Protocol for Asiatic Citrus Canker [16].

\section{Pathogen identification}

Morphological, biochemical and physiological characteristics of bacterium isolates including gram staining reaction, growth on YDC medium, starch hydrolysis, growth at 36 oC and 40 oC test, motility test, anaerobic growth, $\mathrm{KOH}$ Solubility test, (1-3\%) $\mathrm{NaCl}$ Tolerance, gelatin liquefaction test, Tween 80 lipolysis and catalase test have been conducted according to Verniere et al [17], Goszczynska et al [18] and Kidist [19].

\section{Pathogenicity Test}

Pure isolates of the bacterium were grown on nutrient agar plates and incubated at $28^{\circ} \mathrm{C}$ for $24 \mathrm{~h}$. Bacterial cells were then harvested in sterile distilled water by using a sterile glass rod and the bacterial suspension was adjusted finally to give $1.0 \times$ $108 \mathrm{CFU} / \mathrm{mL}$ using a UV spectrophotometer at a wavelength of $600 \mathrm{~nm}$ (Sunrise Spectrophotometer, Tecan). Immature fully expanded 'Mexican' lime and 'Marsh' grapefruit, Valencia orange, Eureka and Mandarin leaves were sterilized by soaking for $2 \mathrm{~min}$ in $1 \%$ sodium hypochloritae followed by rinsing in sterile distilled water. Leaves were placed on the surface of $1 \%$ water agar with their abaxial surfaces facing upwards. Six wounds were made per leaf with a needle and droplets (10 microliters) of bacterial suspensions were placed on each wound. Leaves were incubated at $28^{\circ} \mathrm{C}$ with a photoperiod of $12 \mathrm{~h} \mathrm{light}$ and $12 \mathrm{~h}$ dark for 2 weeks.

\section{Results}

\section{Field survey and disease pathometry}

The survey conducted in commercial citrus orchards and nurseries in both Kassala and Khartoum States indicated the occurrence of citrus bacterial canker (CBC) on lime (Citrus aurantifolia Swingle), but not on the other surveyed citrus varieties. While the typical disease symptoms in Kassala State were evident in both citrus orchards and the nursery lime seedlings, they were only displayed in the nursery stock and absent in orchards in Khartoum State. The combined disease development of the two planting types (orchards and nurseries) in Kassala State was consistently significantly $(\mathrm{P} \leq 0.05)$ higher in Sawagi North compared to that in Sawagi South (Table 1). Separately, CBC development on each planting types was as follows:

\section{i. In orchards}

The results of the disease Incidence, severity, and disease index are shown in Table 1 . The disease was recorded in all surveyed commercial orchards in Kassala State. While Sawagi North recorded significantly $(\mathrm{P} \leq 0.05$ ) higher $\mathrm{CBC}$ incidence (66.6\%) comparatively low disease level was recorded in Sawagi South (18\%). Similarly, more severe CBC (3 fold as much) was encountered in Sawagi North with a disease index, which was significantly $(\mathrm{P} \leq 0.05)$ higher $(64.9 \%)$ than that recorded in Sawagi South $(25.3 \%)$. However, the disease was not detected in citrus orchards in Khartoum State.

\section{ii. In nurseries}

Citrus bacterial canker disease was recorded in all the surveyed nurseries in both locations of Kassala State (Table 1). North Sawagi recorded 51.7\%, 2.1 and 52\% CBC incidence, severity, and disease index, respectively. Comparable CBC development was noticed in South Sawagi indicating 53\%, 1.8 and 51.5\% incidence, severity, and disease index respectively. However, In Khartoum State, the disease was detected in $45 \%$ of lime plants in only one nursery in Khartoum North with an overall mean disease incidence of $12.6 \%$, moreover, 0.7 and $21.2 \%$ CBC severity and disease index were recorded respectively. 
Table 1: Incidence (\%), Severity and disease index (\%) of citrus bacterial canker disease (CBCD) in Kassala and Khartoum states (January 2015).

\begin{tabular}{|c|c|c|c|c|c|c|c|c|c|}
\hline \multirow{2}{*}{} & \multicolumn{3}{|c|}{ Disease incidence (\%) } & \multicolumn{3}{c|}{ Disease severity } & \multicolumn{4}{c|}{ Disease Index (\%) } \\
\hline locations & Orch. & Nurs. & Mean & Orch. & Nurs. & Mean & Orch. & Nurs. & Mean \\
\hline \multirow{2}{*}{ SN } & $\begin{array}{c}66.6 \mathrm{a} \\
(75.5)\end{array}$ & $\begin{array}{c}51.7 \mathrm{a} \\
(61)\end{array}$ & $\begin{array}{c}59.2 \mathrm{~A} \\
(67.7)\end{array}$ & $2.4 \mathrm{a}$ & $2.1 \mathrm{a}$ & $2.2 \mathrm{~A}$ & $\begin{array}{c}64.9 \mathrm{a} \\
(80.5)\end{array}$ & $\begin{array}{c}52.0 \mathrm{a} \\
(61.9)\end{array}$ & $\begin{array}{c}58.4 \mathrm{~A} \\
(71)\end{array}$ \\
\hline \multirow{2}{*}{$\mathrm{SS}$} & $\begin{array}{c}18.0 \mathrm{~b} \\
(21.6)\end{array}$ & $\begin{array}{c}53.6 \mathrm{a} \\
(64)\end{array}$ & $\begin{array}{c}35.8 \mathrm{~B} \\
(42.8)\end{array}$ & $0.8 \mathrm{a}$ & $1.8 \mathrm{a}$ & $1.3 \mathrm{~B}$ & $\begin{array}{c}25.3 \mathrm{~b} \\
(27.3)\end{array}$ & $\begin{array}{c}51.5 \mathrm{a} \\
(62.2)\end{array}$ & $\begin{array}{c}38.8 \mathrm{~B} \\
(44)\end{array}$ \\
\hline \multirow{2}{*}{$\mathrm{KN}$} & $\begin{array}{c}1.81 \mathrm{~b} \\
(0.0)\end{array}$ & $\begin{array}{c}21.6 \mathrm{~b} \\
(12.5)\end{array}$ & $\begin{array}{c}07.2 \mathrm{C} \\
(6.2)\end{array}$ & $0.0 \mathrm{a}$ & $0.0 \mathrm{a}$ & $0.3 \mathrm{C}$ & $\begin{array}{c}1.81 \mathrm{~b} \\
(0.0)\end{array}$ & $\begin{array}{c}21.2 \mathrm{~b} \\
(24.1)\end{array}$ & $\begin{array}{c}11.5 \mathrm{C} \\
(12)\end{array}$ \\
\hline \multirow{2}{*}{$\mathrm{K}$} & $1.81 \mathrm{~b}$ & $\begin{array}{c}1.81 \mathrm{~b} \\
(0.0)\end{array}$ & $\begin{array}{c}1.81 \mathrm{C} \\
(0.0)\end{array}$ & $0.0 \mathrm{a}$ & $0.0 \mathrm{a}$ & $0.0 \mathrm{C}$ & $\begin{array}{c}1.81 \mathrm{~b} \\
(0.0)\end{array}$ & $\begin{array}{c}1.81 \mathrm{~b} \\
(0.0)\end{array}$ & $\begin{array}{c}1.81 \mathrm{C} \\
(0.0)\end{array}$ \\
\hline
\end{tabular}

Means followed by the same letters in each disease pathometry are not statistically different at $P \leq 0.05$.

Orch. $=$ Orchards, Nurs. $=$ Nurseries, $\mathrm{SN}=$ Sawagi North, $\mathrm{SS}=$ Sawagi South, $\mathrm{KN}=$ Khartoum North, $\mathrm{K}=$ Khartoum.

a: Severity scale (SS) units with a minimum of 0 (no disease) and a maximum severity of 5.0.

Figures between parentheses are actual percentage values.

LSD for location at $5 \%=14.4,0.63$ and 16.1 for incidence, severity and disease index, respectively.

\section{Symptomatology and Pathogen Identification}

Typical symptoms were observed upon examination of 'local' lime trees infected with CBC. These characteristic external symptoms were cankerous pustules and necrotic lesions consisting of raised or erumpent corky tissues on leaves, fruits, twigs, thorns, and branches. The canker lesions on leaves and fruits were surrounded by a water-soaked ring and often with a prominent yellow margin. Also, lesions with a shot hole-like appearance were found. Unusual canker lesions were also commonly encountered on the leaves, which were associated with mechanical (i.e. thorn) and leaf miner damages. Many of these canker lesions coalesced to form elongate or blotchy corky patterns on the affected leaves. Frequently, severe infections were encountered in some surveyed orchards which largely covering. In severe cases of foliage infection, extensive leaf defoliation and die-back symptoms were observed. The fruits were particularly susceptible to the canker pathogen, usually developing severe canker lesions with crater-like centers and severe gummy exudates. Which ultimately led to piles of fallen fruits underneath the affected lime trees. In nurseries, severe canker symptoms were also observed on leaves, twigs, and stems The results of biochemical and physiological characteristics of the pathogen are recorded in table 2 :

Table 2: Biochemical and physiological characteristics of Xanthomonas citri subsp. citri, the causal agent of CBCD on lime.

\begin{tabular}{|c|c|c|c|c|}
\hline Test & Khartoum North & Khartoum & Sawagi North & Sawagi South \\
\hline Gram reaction & - & - & - & - \\
\hline Growth on YDC & + & + & + & + \\
\hline Starch hydrolysis & + & + & + & + \\
\hline Growth at $360 \mathrm{C}$ & + & + & + & + \\
\hline Growth at $40 \mathrm{oC}$ & - & - & - & - \\
\hline Motility & + & + & + & + \\
\hline Aerobic growth & + & + & + & + \\
\hline KOH Solubility & + & + & + & + \\
\hline $\operatorname{NaCl}(1-3 \% \mathrm{w} / \mathrm{v})$ & + & + & + & + \\
\hline Gelatin liquefaction & + & + & + & + \\
\hline Tween 80 lipolysis & + & + & + & + \\
\hline Catalase & + & + & + & + \\
\hline
\end{tabular}




\section{Pathogenicity test on detached leaves:}

The typical canker lesions observed on infected lime leaves were reproduced only on lime in response to the pathogenicity test performed on detached leaves. On day 7 post-inoculation small white callus developed on lime leaves at the six inoculation points (Plate 12A). Advanced callus formation gradually changing to tan color lesions surrounded by water-soaked area and yellow halo were produced on lime leaves as time progressed to 20 days after inoculation (Plate 13A). A typical symptom of flat lesions developed on sour orange, 'Valencia' orange, and 'Baladi' mandarin (Plates 13B, 14A, 14B). However, 'Eureka' lemon, 'Merkis' mandarin, and grapefruit (Red blush and March) failed to produce any symptoms (Plates 15 and 16) similar to the control treatment inoculated with sterile distilled water (Figure 1).
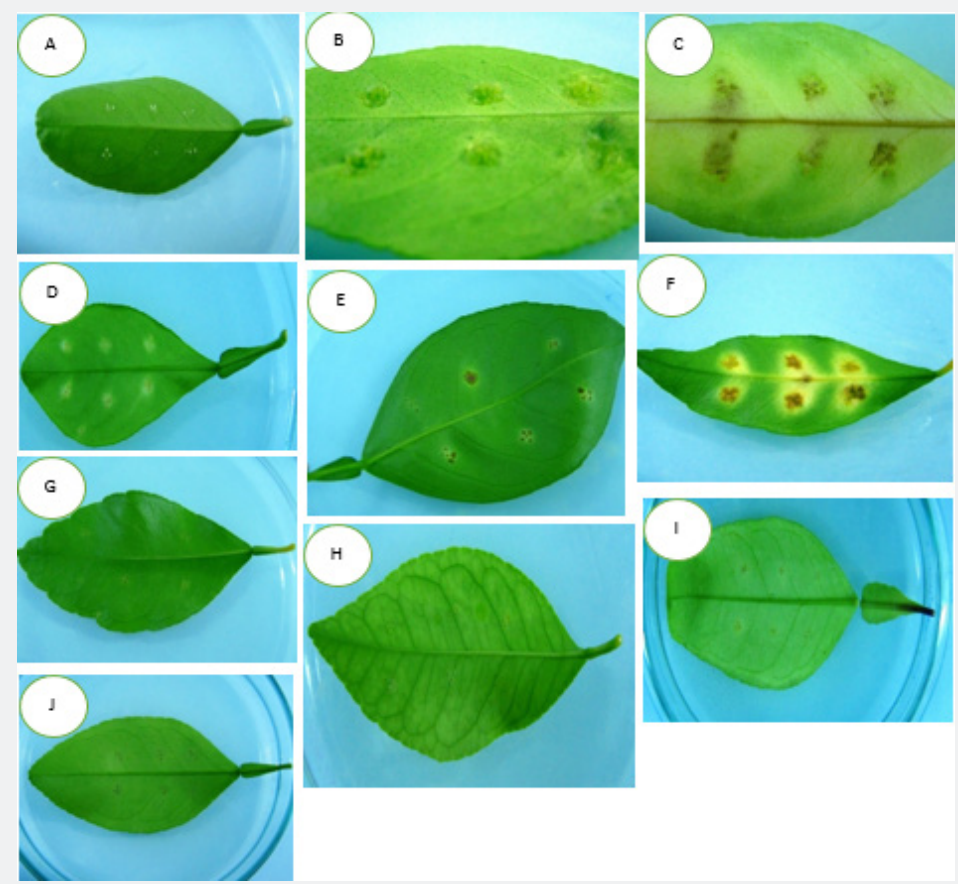

Figure 1: Reaction at (A): day 7 on 'Baladi' Lime inoculated with isolates of citrus canker bacteria showing beginning of white colored callus in all inoculation points, (B): day 14 on 'Baladi' lime showing advanced callus formation with water soaking ring. Reaction at day 20 on (C): 'Baladi' Lime showing advanced, tan colored callus with chlorosis and water soaking, and (D): sour orange showing callus formation with flat appearance. Reaction at day 10 on (E): 'Valencia' orange showing flat necrotic lesions with water soaked margin, and (F): 'Baladi' mandarin inoculated with same isolated bacteria showing advanced, tan colored flat lesion with chlorosis and water soaking.. Reaction at day 20 on (G): 'Merkis' mandarin showing no symptoms in all inoculation points, and $(\mathrm{H})$ : on 'Eureka' lemon indicating no symptoms in all inoculation points. Reaction at day 20 on (I): 'March' grape fruit and (J): 'Red blush' grape fruit showing no symptoms.

\section{Discussion}

The citrus bacterial canker disease (CBCD) has become established and attained an epidemic status in different parts of Sudan. Although the disease has not been known before 2013, its emergence in autumn 2014 was somewhat overwhelming and so intriguing. It infested the main citrus growing areas of Kassala State which represents the most important commercial producing region in the country, particularly the North Sawagi and the South Sawagi localities recording considerably high CBCD levels (incidence of $66.6 \%$ and $18 \%$ and disease indexes of $64.9 \%$ and $25.3 \%$, respectively). This outbreak is believed to have been caused through a long-distance spread, which more often occurs with the movement of infected propagating materials such as nursery stocks, budwood or budded trees, or through contaminated environmental factors such as nursery workers carrying the bacteria on hands, clothes, and contaminated budding tools [11]. Alternatively, the spread of canker bacteria may have occurred during strong wind-driven rains coming from Gadaref State or across the borders from Ethiopia (Derso et al., 2009) or Saudi Arabia [6]. The fact that CBCD was first detected in some Gadaref State localities only a year before it appeared in Kassala, would indicate that the path of the disease was most likely: Ethiopia- Gadaref then Kassala. This could be substantiated by the discovery of the disease several years ago in Ethiopia (Derso et al., 2009) and only recently in commercial citrus orchards and nurseries of Gadaref State [20]. The bacterial inoculum might have been present in Kassala in the same year of the discovery of CBCD in Gadaref, but it has been overlooked since the pathogen is known to survive epiphytically at low population levels on citrus hosts without symptoms development, and in association 
with other weeds and grass hosts $[21,22]$. However, the bacteria survive primarily in naturally occurring lesions. Cankerous leaves, twigs, and branches constitute the main source of the inoculum, but the prominent occurrence of lesions is seasonal, coinciding with periods of heavy rainfall, moderate temperature, and growth flushes. The pathogen can survive up to 6 months or more in the infected leaves [23] and up to 76 months on diseased twigs [24].

In comparison, the greater CBCD development in the Northern Sawagi over that in the Southern Sawagi can be attributed mainly to the topographical factors of Kassala State heights $(\leq 850 \mathrm{~m}$ a.s.l). These heights may retard the wind speed in South Sawagi, while in North Sawagi orchards on the other side exposed to winddriven that may carry the bacterial inoculum. Also, the variation of disease pathometry may have a direct relation to differences in the prevailing cropping systems in the two locations. For instance, the mixed plantation of lime /mango system makes southern Sawagi trees less infected because of the windbreak effect created by mango trees. This is not surprising since cankers develop more severely on the side of the tree exposed to wind-driven rain. [25]. Although this variation in CBCD level is perceivable in the first year of the appearance of the disease, it is unlikely to persist if the locally prevailing epidemiological factors remain remarkably similar in the two locations.

On the other hand, CBCD was absent in Khartoum State, be it in commercial citrus orchards or nurseries, except in one nursery of lime seedlings in Khartoum North. This was perceivable since the prevailing environmental conditions were not conducive for CBCD development [26]. The remarkably high CBCD incidence reported in that nursery (45\%), however, was believed to have resulted from a consignment of infected nursery stock brought from infested wet areas such as Kassala or Gadaref. It may constitute a potential threat, at least in localized small pockets in Khartoum State where the temperature and humidity may allow for a limited occurrence and spread of the disease. The study also demonstrated that the epidemic was naturally occurring and spreading on acid lime trees (Citrus aurantifolia) but not on other citrus varieties, even if they were close to the diseased lime trees. This strongly indicates that this citrus canker bacterial isolate is restricted to lime. The host specificity of this canker bacterium to lime was like that from Gadaref [20], which would further support the notion that it originated from Gadaref. The canker bacterium isolates which are specific to lime have also been previously reported from Maldive islands [26], Southwest Asia [5], Ethiopia (Derso et al., 2009), and the western region of Saudi Arabia [6]. The fact that the pathogenicity tests of the isolated bacterium developed characteristic lesions only upon artificial inoculation of detached leaves of lime and failed to induce any cankerous lesions typical of citrus bacterial canker (CBC) on grapefruit, sweet orange, or on other citrus varieties tested was a strong indication that the present bacterial isolate may belong to a special group of strains designated as pathotype $\mathrm{A}^{*}$. Although closely related to the ordinary A pathotype, these strains can be readily distinguished from the former, based on their atypical combination of host range and symptomatology [5]. Additional strains with similar biological behavior were reported by [7] and were also included in this distinctive group (i.e. $\mathrm{A}^{*}$ ). Although this bioassay has been found in both specific and sensitive diagnostic methods for CBC [8] the molecular analysis will certainly establish the correct identity of the bacterial isolates spreading in Kassala and elsewhere in Sudan. Collectively, the association and isolation of Xanthomonas sp. from symptomatic lime trees, together with the symptomatology, biochemical characterization, and pathogenicity tests strongly indicate that the currently investigated disease on lime in Kassala and Khartoum states is CBC (X. citri subsp. citri) and these lime isolates are closely related to the strains of the atypical Asiatic pathotype (Xcc- $A^{*}$ ) [27-32].

\section{Acknowledgement}

We greatly thank Dr. Mohamad Yousif, University of Bahri, Department of Plant Health for his unlimited support and guidance. We also owe a lot to Prof. Abdel Wahab H. Abdulla (Department of Agronomy Faculty of Agric., University of Khartoum) for his patience and assistance with the experimental design and statistical analyses of the results.

\section{References}

1. Mahdi EM (1979) Studies of the nutritional status of selected citrus orchards in shambat. M.Sc. Thesis, University of Khartoum. Sudan.

2. Sidahmed OA, Geneif AA (1984) Performance of citrus in the irrigated heavy clay soils of central Sudan. 1Lemon. Acta Hort $8^{\text {th }}$ African Symposium on Hort. Crops143: 247-255.

3. Abubaker MYA (2009) Detection and diagnosis of important virus and virus-like diseases in commercial citrus orchards in some tropical areas of Sudan. Ph.D. Thesis, U of K. Sudan.

4. Elhassan SM, Ali O, Yousif N (2014) Anew aggressive bacterial disease on baladi lime in Gadaref area. The $3^{\text {rd }}$ conference on Pest management in Sudan. Agricultural Research Corporation (ARC). Crop Protection Centre, Wad Medani, Sudan.

5. Verniere C, Hartung JS, Pruvost OP, Civerolo EL, Álvarez AM, et al. (1998) Characterization of phenotypically distinct strains of Xanthomonas axonopodis pv. citri from Southwest Asia. European Journal of Plant Pathology104: 477- 487.

6. Al-Saleh MA, Widyawan A, Saleh AA, Ibrahim YE (2014) Distribution and pathotype identification of Xanthomonas citri subsp. citri recovered from southwestern region of Saudi Arabia. African J. of Microbiology Research 8(7): 673-679.

7. Zekri M, Chamberlain H, Timmer P, Roberts P, Muchove R (2005) Field identification of citrus canker symptoms and decontamination procedures. Uni. IFAS extension, Florida.

8. Graham JH, Gottwald TR, Cubero J, Achor DS (2004) Xanthomonas axonopodis pv. citri: factors affecting successful eradication of citrus canker. Mol. Plant Pathol. 5(1): 1-15.

9. Schubert TS, Sun X (2003) Bacterial citrus canker. Plant Pathol. Circular No. 377. Fl. Dep. Agric. and Cons. Services. Division. Plant industry. pp. $1-6$.

10. Burning A.M, Gabriel DW (2003) Xanthomonas citri: breaking the surface. Mol. Plant Pathol. 4(3): 141-157. 
11. Das AK (2003) Citrus canker-A review. J. Appl. Hort. 5(1): 52-60.

12. Bergamin-Filho A, Amorim L, Laranjeria L, Gottwald TR (2000) Epidemiology of citrus canker in Brazil with and without the Asian citrus leafminer. In: Proceedings of the International citrus canker Research Workshop, Ft. Pierce, Florida.

13. Stall RE, Senymour CP (1983) Canker, a threat to citrus in the Gulfcoast States. Plant Dis. 67: 581-585.

14. Graham JH, Gottwald TR (1991) Research perspectives on eradication of citrus bacterial canker diseases in Florida. Plant Disease 75: 11931200 .

15. Schubert TS, Rizvi SA, Sun X, Gottwald TR, Graham JH, et al. (2001) Meeting the challenge of eradicating citrus canker in Florida Again. Plant Disease 85(4): 340-356

16. NDP (2014) National Diagnostic Protocol for Asiatic Citrus Canker Xanthomonas citri subsp. citri. Department of Agriculture, Australian Government, pp. 33.

17. Verniere C, Devaux M, Pruvost OP, Couteau A, Luisetti J (1991) Studies on biochemical and physiological variation among strains of Xanthomonas campestris pv. citri, the causal agent of citrus bacterial canker disease. Fruits 46(2): 162-170.

18. Goszczynska T, Serfontein JJ, Serfontein S (2000) Introduction to practical phytobacteriology. SAFRINET. The Southern African (SADC) Loop of Bin Net-International.

19. Kidist B (2003) Characterization of Xanthomonas campestris pv. musacearum isolates, causal agent of ensete bacterial wilt diseases. M. Sc. Thesis. Addis Ababa University. Ethiopia.

20. Abubaker MYA, Abu Dibar OAB, Elhassan SM, Yousif NME (2016) First report of citrus bacterial canker disease in lime (Citrus aurantifolia Swingle) in Gadaref State-Eastern Sudan. Agric. Biol. J. N. Am.7(5): 263-274.

21. Goto M (1972) Survival of Xanthomonas citri in the bark tissues of citrus trees. Can. J. Bot.50(12): 2629-2635
22. Ali Dinar HM (1984) Performance of several citrus cultivars in the arid region of Northern Sudan. Eighth African Symposium on Hort. Acta. Hort. Crops 143 239-243.

23. Vasudeva RS (1958) Sci. Rep. Indian Agric. Res. Inst., New Delhi,1956-1957, p. 93.

24. Chakravarti BP, Porwal S, Rangarajan M (1966) Studies on citrus canker in Rajasthan. I. Disease incidence and survival of the Pathogen. Labdev J. Sci. Tech.4: 262-265.

25. Stall RE, Miller JW, Marco GM, Canteros B (1980) Population dynamics of Xanthomonas citri causing cancrosis of citrus in Argentina. Proceeding of Fla. state horticulture society 93: 10-14

26. Roistacher CN, Civerolo E L (1989) Citrus bacterial canker disease of lime trees in the Maldive Islands. Plant Disease 73: 363-367.

27. Verdier E, Zefferino E, Mendez S (2008) Survival of Xanthomonas axonopodis pv. citri on the surface of citrus fruit after postharvest treatment. Fitopatologia 43: 24-31.

28. Al-Saleh MA, Ibrahim YE (2010) Population dynamics of Xanthomonas citri subsp. citri on symptomless citrus fruits under Saudi Arabia conditions and effect of post-harvest treatments on survival of the bacteria. Journal of Plant Pathology 92(3): 601-605.

29. Gomez KA, Gomez AA (1984) Statistical procedure for Agriculture research $2^{\text {nd }}$ edn., Johan Willy and Sons Inc. New York, USA.

30. Leite RP, Mohr SK (1984) Survival of Xanthomonas campestris pv. citri (Hasse) Dye in soil and in association with some gramineous plants. Proc. Intn. Soc. Citric.2, 365-368.

31. Lin HC, Chang H, Tzeng KC (2008) Characterization of Novel Strain of Citrus Canker Bacterium from Citrus in Taiwan J. Taiwan Agric. Res. 57(4): 265-278.

32. Vauterin L, Hoste B, Kersters K, Swings J (1995) Reclassification of Xanthomonas. International Journal of Systematic Bacteriology 45(3): 472- 489

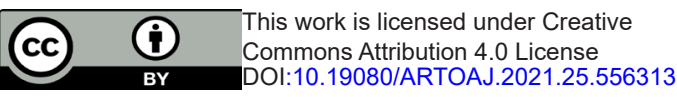

\section{Your next submission with Juniper Publishers will reach you the below assets}

- Quality Editorial service

- Swift Peer Review

- Reprints availability

- E-prints Service

- Manuscript Podcast for convenient understanding

- Global attainment for your research

- Manuscript accessibility in different formats ( Pdf, E-pub, Full Text, Audio)

- Unceasing customer service

Track the below URL for one-step submission https://juniperpublishers.com/online-submission.php 